\title{
Identification of Classroom Physical Environmental for Wheelchair Users in Inclusive Schools
}

\author{
Dwi Arnia Ulfa*; Sunardi Sunardi; Zaini Rohmad \\ Department of Special Education, Universitas Sebelas Maret, Indonesia \\ Email: dwiarniaulfa@gmail.com
}

http://dx.doi.org/10.18415/ijmmu.v5i5.413

\begin{abstract}
This study aims to determine the classroom physical environment of wheelchair users in inclusive schools. This research was conducted in two inclusion schools in Surakarta City. This study used descriptive qualitative method. Data collection is done by interview, observation and documentation. The results showed that some of the things that teachers have done related classroom arrange for wheelchair users are an easy door for wheelchair users, non-slip floors, seating is easy to reach by students, provided ventilation and light enough, and available device have been modified. While the obstacles experienced by wheelchair users are the distance between the table is difficult to pass the wheelchair, difficulty in using modified device, difficulty move in building multi-storey school building and path to a class that has not been smooth.
\end{abstract}

Keywords: Physical Environment Arrange; Classroom; Wheelchair Users

\section{Introduction}

Children with physical disabilities is a child who has a disorder or a permanent disability in motion (bone, joints, muscles) in such a way that requires special educational services (Karyana and Widati., 2013: 32). Due to abnormalities of the movement of the equipment experienced, the child is experiencing obstacles in moving obstacles (ambulation), and coordination/ balance the body. This causes a disruption in performing daily activities. In order for the children with physical disabilities to conduct ambulation and activity of daily life (life of daily living), it is necessary to use tools (Budiyanto et al., 2013: 124).

One of the tools used by the children with physical disabilities is a wheelchair. The wheelchair should be used in a child who is actually a weakened tough leg muscles and abdomen that no longer possible to be trained to stand and walk (Karyana and Widati., 2013: 114). With the wheelchair then the tunadaksa can perform daily activities, including access to education.

Inclusive education is one form of educational services for students wheelchair users. Through inclusive education, children with special needs are educated together with other children to optimize their potential (Freilberg, in Budiyanto et al., 2013). In the implementation of inclusive education for 
wheelchair users, there is a need for special arrangements related to the learning environment, especially the physical environment of the classroom. This is because the classroom is used as a place of teaching and learning activities take place so that the need for adjustment related barriers students wheelchair users in the classroom. Based on research Kartikasari (2014) found that modified classroom settings can improve learning to be more effective, because it is able to maintain the concentration of students in receiving the subject matter, especially for students with special needs. In addition, students with special needs more easily socialize with friends in the class so that students do not feel different from other students.

Given that the physical arrange of the classroom are important for wheelchair users, the researcher is interested in finding out more about the field picture of the physical environment of the classroom for wheelchair users in inclusive schools.

\section{Methodology}

The research method used in this research is descriptive qualitative method. Nawawi (1983: 63) states that descriptive method is a problem-solving procedure that is investigated by describing or describing the state of subject or research object (someone, institution, society and others) at present based on facts that appear or as it should be. In other words, this descriptive method is used to describe the state of the classroom in the study site.

The location of the research was conducted in two inclusive schools located in the city of Surakarta. There is "X" Elementary School and "Y" Junior High School and both of schools are inclusion schools that have students wheelchair users.

Data collection techniques in this study are interviews, observation and documentation. Interviews were conducted to teachers and wheelchair users for information about the physical environment of the classroom and the constraints faced by wheelchair users. Observations were made for the process of direct observation of the physical environment of inclusive school classrooms. While the documentation is done to collect documents in the form of photographs related to the physical environment of the classroom in inclusive schools.

The findings are further represented and analyzed descriptively. Identify the needs of the physical arrangement of classrooms for wheelchair users can be made based on findings on the problems found in the classroom arrange.

\section{Result and Analysis}

The results of interviews that researchers have done to teachers, found that there are some things that have been done by teachers in regulating the physical environment of the classroom, namely:

\section{a. Door}

"X" Elementary School has a door made of wood. The door of the classroom in "X" Elementary School consists of two doors which are on the right and left. The classroom entrance is easy for wheelchair users to pass by. In addition, wheelchair users easily enter the classroom because the floor height is not more than three centimeters. "Y" Junior High School has a classroom door made of wood. Unlike the door at Pajang 1 Elementary School, the door of the classroom in "Y" Junior High School 
consists of only one door. The classroom door is easy to use for wheelchair users because it has a wider size than a wheelchair. The classroom entrance is also easy to pass by wheelchair users because it has a floor height of no more than three centimeters.

\section{b. Floor}

The floor of the classroom in "X" Elementary School is made of ceramic material and does not cause slippery. In addition, the classroom floor is also flat so it is safe for wheelchair users. Similarly, the floor of "Y" Junior High School classroom. The floor of "Y" Junior High School classroom is made of ceramic material and does not cause slippery and smooth, so wheelchair users are safe when mobilizing on the floor of the classroom.

\section{c. $\quad$ Seating Arrangements}

"X" Elementary School has two students of wheelchair users. While "Y" Junior High School has a student wheelchair user. The teacher of "X" Elementary School stated that the seating arrangement of the wheelchair user in the classroom is placed on the front. This is done to facilitate students wheelchair users to his desk. Similarly, the seating arrangement in the "Y" Junior High School classroom for wheelchair users is also placed on the front to facilitate the mobilization in the classroom.

\section{d. Ventilation and Light Setting}

The classrooms in "X" Elementary School have windows with ventilation made of wire. This window facilitates the entry of air and sunlight so that the classroom has a good exchange and enough light. "Y" Junior High School has wooden windows that are wide in size, making it easy for air exchange and sunlight into the classroom. In addition, there is a fan in the classroom that can be used at a time when learning activities take place, especially when the hot air and the need to close the window when making a presentation using LCD projector.

\section{e. $\quad$ Facilities}

Students of wheelchair users in " $X$ " Elementary School have modified facilities such as wheelchairs and desks. The table can be mounted and released in the student's wheelchair. While "Y" Junior High School has a table that has been modified for students who use wheelchairs. The table has a larger size than other tables. With this table is expected students wheelchair users easy to get out and enter the table.

While based on the results of interviews with students using wheelchair users, obtained some barriers experienced by students using wheelchairs related to the physical classroom environment arrange, namely:

a. Students of wheelchair users in "Y" Junior High School complained about the difficulty of mobilization in the classroom because of the bulkhead between desks which is still difficult to be passed by wheelchair. 
b. After that, the table that has been modified is still not in accordance with the needs of students wheelchair users. Students using wheelchairs find it difficult to use modified desks because they are too big and complicate when entering and exiting the table.

c. The wheelchair student feels difficult when heading to the computer lab room because it is located on the third floor. This makes it difficult for students who use wheelchairs so that when moving to a computer lab located on the third floor, students are wheelchair users picked up by teachers and friends.

d. In addition, the students of the seat users feel the way to the classroom has not been access for wheelchair users such as uneven roads and there is a floor height that is difficult to pass the wheelchair users independently.

Based on the results of the study it was found that classroom doors in inclusive schools are already accessible for use by wheelchair users. According to Unesco (2006: 31) classroom door should be made as wide as possible for easy wheelchair. Unesco (2007: 44) adds a few points to note concerning the accessible classroom doors in the inclusion school, which has a door width of about $160 \mathrm{~cm}$, is easy to open and close, closes to the wall when the door opens, the floor between the classroom and the courtyard the class should be equally equipped with texture, and different colors on the front door or if there is a distance given with a slick material that is not slippery.

Material selection is a matter of concern for the school floor. According to Unicef (2014: 20) some floor barriers are glazed tiles or marble, very slippery tiles, uneven and unkempt surfaces that can be difficult for everyone, especially for children with special needs. According ASB (2016: 24) the selection of floor materials to note, because if the floor surface is slippery it can make wheelchair users slip. In addition, according to Nuri and Rullan (2013) the difference in floor height should not be more than $3 \mathrm{~cm}$. If the floor height difference is more than $3 \mathrm{~cm}$ then it will cause the wheelchair user difficulty mobilization so that should provide the ramp area.

Seating arrangements are important for students with disabilities in inclusive schools. Seating arrangements for wheelchair users have been done well. Students of wheelchair users are placed in the middle of the front with the intention that students are easy wheelchair users to the seat. According to Unesco (2007: 45) the location of the table in the classroom should be easy to reach by students wheelchair users. Hermawan (2012: 62) adds because of the physical condition possessed by the students are quadriplegic, including the students wheelchair users, preferably the position of his seat in an easy place, flexible, and communicative.

A good classroom should have a window for the classroom to have adequate lighting and smooth air circulation. "X" Elementary School and "Y" Junior High School have windows in the classroom so that they have sufficient light and smooth circulation. According to Permendiknas (2008) classrooms that have windows allow adequate lighting to read books and to provide an outdoors view.

Barriers experienced by wheelchair users require modified facilities, such as desks in the classroom. According to Unesco (2006: 56), children with disabilities sometimes need to use their own items, such as ergonomic chairs and sloping desks. These needs should be accommodated in such a way without impairing the other children. In line with this, Karyana and Widati (2013: 92) state that the class should be equipped with tables and chairs whose construction is adapted to the child's disability conditions, such as adjustable seat height, handlebar and chair backrest, and belt mounted (belt) for safety. However, regardless of this, the school needs to seek opinions and suggestions from wheelchair users about modified facilities, especially desks so that wheelchair users do not find it difficult to use the desks that have been provided. 
Setting the physical environment for wheelchair users in inclusive schools has several obstacles. the distance between the table is often still a barrier of students wheelchair users when in the classroom. According to Unesco (2006: 56) children wheelchair users, capillaries or crutches for mobility may find it difficult to move around in a traditional classroom setting filled with rows of chairs and tables. Therefore, it is important that the class be arranged in such a way that all children can move freely. Unesco (2006: 30) added that in arranging the distance between tables in the class needs to consider the mobility of a wheelchair. The width of the standard wheelchair is 80 centimeters, so that the wheelchair can be passed the table spacing should be more than 80 centimeters.

Classroom locations for wheelchair users need special attention, especially in school buildings that have high rise buildings. The classroom for wheelchair users should be from the start on the first floor only. In addition to the classroom, the room that could be used by regular students and students wheelchair users together also placed on the first floor, such as Computer Laboratory, Biology Laboratory, language laboratory, art room, library, and so forth. This is supported by the statement of Unesco (2006: 31) stating that if in school only the first floor is accessible, so make sure all class students in which there are students with a quadriplegic (eg wheelchair/ crutch) are placed only on the first floor only. If the classroom or laboratory room is located on the first floor, then the wheelchair user does not need to be picked up to reach the room.

Uneven roads become a problem for wheelchair users. This causes students wheelchair users trouble when mobilization. According to Karyana and Widati (2013: 91) the access road to the school should be made loud and flat that allowing the disabled child who uses ambulatory aids, such as a wheelchair, tripor, brace, crutches and others, can move safely. In addition, there is a need for ramps that can be used for the mobilization of wheelchair users when there is a difference in floor height. Unesco (2007: 44) states that the school yard that facilitates the mobilization of wheelchair users is to have a sliding gate and easy and light to open and close, the school bridge is closed without the holes in the middle, the floor is flat, or equipped with ramp.

\section{Conclusion}

Based on the results of the research note that some things that have been done by teachers related to the physical environment settings of the classroom for wheelchair users is a classroom door that is easy to pass by wheelchair users, the floor is not slippery and safe for students, the placement of students using wheelchair in the front so as to facilitate the students to his desk, a classroom that has adequate ventilation and lighting so that air circulation smoothly and classrooms have adequate lighting and provide modified facilities. While the obstacles felt by wheelchair students are the distance between desks in the class that are difficult to pass by wheelchairs, difficulty in using modified desks, wheelchair users have not been able to move while in school, especially when moving floors, picked up and the path to the class is still not flat and has a floor height that is difficult to pass by wheelchair.

\section{Suggestion}

The suggestion that can be given in this research is to consider the physical environment of the classroom of wheelchair users, especially the obstacles experienced by wheelchair users so that the wheelchair users easily move around inside and outside the classroom. 


\section{References}

ASB. (2009). Aksesibilitas Fisik. Yogyakarta: Arbeiter-Samariter-Bund Deutschland.

Budiyanto, Prapto, M. Yusuf, Sujarwanto, A. A. Sopandi, dan T. Rakhmita. (2013). Modul Pelatihan Pendidikan Inklusif. Jakarta: Kementerian Pendidikan Dan Kebudayaan Direktorat Jenderal Pendidikan Dasar Direktorat Pembinaan PKLK Dikdas.

Hermawan. (2012). Pengelolaan Kelas Anak Berkebutuhan Khusus. Surakarta: UNS Press.

Kartikasari, OD. (2014). Manajemen Sarana dan Prasarana Pembelajaran di SD Tumbuh 1 Yogyakarta. Skripsi. (online). (http://eprints.uny.ac.id/18859/1/Oktina\%20Dwi\%20Kartikasari.pdf).

Karyana, A dan S. Widati. (2013). Pendidikan Anak Berkebutuhan Khusus Tunadaksa: Peserta Didik Berkebutuhan Khusus dengan Hambatan Gerak. Jakarta: PT. Luxima Metro Media.

Nawawi, H. H. (1983). Metode Penelitian Deskriptif. Gajah Mada University Press. Yogyakarta.

Permendiknas RI No. 24 tahun 2008 tentang Standar Sarana dan Prasarana untuk Sekolah Dasar Luar Biasa (SDLB), Sekolah Menengah Pertama Luar Biasa (SMPLB), dan Sekolah Menengah Atas Luar Biasa (SMALB).

UNESCO. (2006). LIRP-Merangkul Perbedaan: Perangkat untuk Mengembangkan Lingkungan Inklusif Ramah terhadap Pembelajaran (Buku Khusus 3: Mengajar Anak-Anak dengan Disabilitas dalam Seting Inklusif). Jakarta: IDP Norway.

UNESCO. (2007). Tulkit LIRP-Merangkul Perbedaan: Perangkat untuk Mengembangkan Lingkungan Inklusif Ramah terhadap Pembelajaran, Buku 6: Menciptakan Lingkungan Inklusif, Ramah Terhadap Pembelajaran yang Aman dan Sehat. Jakarta:IDPN Indonesia.

UNICEF. (2014). Access to School and the Learning Environment I- Physical, Information and Communication (Companion Technical Booklet). New York: UNICEF.

Widi, NA dan R. Nirwansyah. (2013). Penerapan Aksesibilitas pada Desain Fasilitas Pendidikan Sekolah Luar Biasa. Jurnal Sains dan Seni Pomits. 2(2): 1-6.

\section{Copyrights}

Copyright for this article is retained by the author(s), with first publication rights granted to the journal.

This is an open-access article distributed under the terms and conditions of the Creative Commons Attribution license (http://creativecommons.org/licenses/by/4.0/). 